\title{
EXPERIENCE WITH PREPARATION OF AN INACTIVATED VACCINE AGAINST AUJESZKY'S DISEASE
}

\author{
L. DEDEK and J. JER̂́BEK
}

Bioveta, 68323 Ivanovice na Hané; Department of Prevention of Pig Diseases, Animal Breeding and Zoohygiene, University of Veterinary Science, 61242 Brno

Dedicated to the 60th birthday of Prof. MVDr. Jaroslav Dražan, CSc.

Received, April 7, 1981

\begin{abstract}
Dedek L., J. Jeřábek: Experience with Preparation of an Inactived Vaccine against Aujeszky's Disease. Acta vet. Brno, 50, 1981: 221-227.

Cell lines IBRS-2, PK-C or primary porcine kidney cells are the most suitable ones for Aujeszky's disease virus propagation for preparation of an inactivated vaccine. Glutaraldehyde-inactivated virus of the Aujeszky's disease proved to be safe in mice and rabbits. Effectiveness of the vaccine was tested in rabbits. Their vaccination followed by revaccination generated immunity for 6 months. Lyophilized inactivated vaccine can be stored for long periods without loss of effectiveness. The vaccine is reconstituted immediately before use by the supplied diluting fluid containing a lipoid adjuvant.
\end{abstract}

Aujeszky's disease, preparation, inactivated vaccine, cell cultures, glutaraldehyde, safety and potency.

Pork meat production is largely dependent upon sufficient numbers of healthy feedlot piglets. Their successfull rearing, however, may be threatened, especially under large-scale systems, by Aujeszky's disease.

In Czechoslovakia, live vaccines have been used to date for immunoprophylaxis of Aujeszky's disease. They were prepared from avirulent Aujeszky's disease viral strains and at the time of their introduction they yielded better results than aluminium hydroxide-inactivated vaccines. The avirulent vaccines decreased considerably animal loss in pig populations.

Recent knowledge of new inactivation substances and the use of adjuvants for potentiation of the antibody response when administered with various antigens enabled the preparation of a new, potent inactivated vaccine against Aujeszky's disease.

Both live avirulent and inactivated vaccines against Aujeszky's disease must contain sufficient amounts of virus. So, for instance, only a sufficient viral content $\left(10^{5} \mathrm{TCID}_{50}\right)$ of the avirulent strain BUK-TK-300/9,2 can induce a good antibody response in sheep ( $\breve{Z u f f a} 1972$ ). For preparation of inactivated vaccines viral suspensions with substantially higher viral titers are employed (from $10^{7.5}$ to $10^{9} / \mathrm{cm}^{3}$ ). For preparation of an inactivated vaccine the Aujeszky's disease virus propagated in hamster kidney cell line BHK-21 was used by Wittmann and Jakubík (1977). They obtained a viral titer of $10^{8.5}-10^{9} \mathrm{TCID}_{50} / \mathrm{cm}^{3}$.

For virus inactivation, various agents have been used. Ethylenimine was used by Wittmann and Jakubík (1977), acetylethylenimine by Gutenkunst (1978), betapropiolactone by Frescura et al. (1977), glutaraldehyde or formaldehyde by Toma et al. (1975), formaldehyde by $\breve{Z} u f f a$ and Neurath (1962), alcohol and saponine by Žuffa et al. (1978). Inactivation by gamma-irradiation at a dose of $0.5 \mathrm{Mrad}$ was used by Dilovski (1973). Possibilities of Aujeszky's disease virus inactivation by ultraviolet light were explored by Lai and Jong (1980).

To increase the antibody response to inactivated vaccines against Aujeszky's disease, Toma et al. (1975) and Delagneau et al. (1975) employed vaseline oil, mannit and emulgin, Wittmann and Jakubík (1977) used DEAE-D, Frescura et al. (1977) used Marcol 52 and Arlacel 80, Lukert et al. (1978) used Tween 80, mineral oil and Arlacel. Gutenkunst (1978) followed the immune response after a vaccine supplemented with lauric acid and aluminium hydroxide. 
Žuffa et al. (1978) employed Marcol, Arlacel and Tween 80. All above-mentioned vaccines supplemented with agents potentiating the immune response were liquid.

The present paper deals with preparation of a lyophilized inactivated vaccine against Aujeszky's disease and its testing in experimental animals - rabbits.

\section{Materials and Methods}

\section{Aujeszky's disease virus}

Cell cultures were infected with Aujeszky's disease (AD) virus isolated from cattle and propagated in cell line PK-Č.

Potency of the prepared inactivated vaccine was tested by challenging the experimental rabbits infected with a virulent AD virus - lyophilized strain B/200 (Institute for State Control of Veterinary Biologicals and Drugs, Brno).

\section{Cell cultures}

Cell lines PK-C and primary cell cultures from pig kidney cultivated in Earle's solution with LAH were tested for suitability for AD virus propagation. We further tested a cell line from porcine kidney cortex IBRS-2 cultivated in Hanks' medium, a rabbit kidney cell line $\mathrm{RK}_{13}$, and a monkey kidney cell line VERO cultivated in MEM (Eagle) medium.

\section{Virus inactivation}

A suitable concentration of the inactivation agent was determined using the viral titer of $10^{8 \cdot 9}$ $\operatorname{TCID}_{50} / 1 \mathrm{~cm}^{3}$. From inactivation agents glutaraldehyde was tested at final concentrations of $0.025 \%, 0.05 \%, 0.1 \%$ and $0.2 \%$ added to the viral samples. The mixture of the virus and glutaraldehyde was incubated for 2 hours at $34^{\circ} \mathrm{C}$ in a water bath in tightly closed vials. The inactivated substance at each of the above-mentioned dilutions was injected intracerebrally into mice weighing $10 \mathrm{~g}$ at doses of $0.03 \mathrm{~cm}^{3}$. The animals were observed for 6 days after inoculation.

\section{Vaccine preparation}

The virus for vaccine preparation was propagated in 3-to-4-day old cell line IBRS-2, infected with $0.05 \mathrm{TCID}_{50}$ of virus per cell. The infected cell culture was cultivated in the maintenance medium without serum at $37^{\circ} \mathrm{C}$ for 36 to 48 hours. Within this time a marked cytopathic effect occurred. The harvested viral suspension was homogenized, stored at $+4{ }^{\circ} \mathrm{C}$ and then tested for sterility. The virus titer was determined. Preparation of the vaccine required $10^{7}$ to $10^{8}$ of viral TCID $_{50}$ per $1 \mathrm{~cm}^{3}$. Before the vaccine preparation proper the cell debris was eliminated by centrifugation or filtration. The virus was inactivated by glutaraldehyde at $0.15 \%$ concentration for 2 hours at $34^{\circ} \mathrm{C}$. From the inactivated product a sample was taken for inactivation control in mice. The product was mixed with the lyophilic medium and lyophilized.

The lyophilized vaccine was reconstituted in a solvent serving also as a lipoid adjuvant. The solvent was composed of distilled water, paraffin oil, pharmaceutical lanolin and Tween 80 .

\section{Safety and potency tests}

were performed in groups of rabbits weighing $2-2.5 \mathrm{~kg}$ ( 3 animals per group). The rabbits were inoculated i. $\mathrm{m}$. (thigh muscles) with various amounts of the vaccination dose for pigs (see Table 1) amounting $5 \mathrm{~cm}^{3}$ (Jeřábek and Dedek 1981). Eleven days later the rabbits were revaccinated with the same dose and in the same way. Ten days later (i. e. 21 days after the vaccination) all rabbits, including the control animals, were challenged by the virulent $A D$ virus at a dose of $1 \mathrm{~cm}^{3}$ containing $10^{5} \mathrm{LD}_{50}$ for rabbits. The viral suspension was administered into the thigh musculature of the intact hind limb. An observation period of 14 days followed.

\section{Evaluation of the safety test}

None in the vaccinated rabbits may show symptoms of AD during the 11-day observation period after the first vaccination and they may not exhibit overall or local postvaccination reactions.

\section{Evaluation of the potency test}

The vaccine must protect $100 \%$ of the experimental animals against a challenge by $A D$ virus in groups 1, 2, 3 (see Table 1). Animals of the groups 4 and 5 may die. All animals of the control group should die within the 14-day observation period after the challenge (Delagneau et al. 1975). 
Table 1

Vaccine safety and potency test in rabbits

$\begin{array}{lllll}\text { Group } 1 & - & \text { Total vaccination dose } & - & 5 \mathrm{~cm}^{3} \\ \text { Group 2 } & - & \text { A half of the vaccination dose } & - & 2.5 \mathrm{~cm}^{3} \\ \text { Group 3 } & - & \text { A quarter of the vaccination dose } & - & 1.25 \mathrm{~cm}^{3} \\ \text { Group 4 } & - & \text { A tenth of the vaccination dose } & - & 0.5 \mathrm{~cm}^{3} \\ \text { Group 5 } & - & \text { A twentieth of the vaccination dose } & - & 0.25 \mathrm{~cm}^{3} \\ \text { Group 6 } & - & \text { A control nonvaccinated group } & & \end{array}$

Observation of immunity development in vaccinated rabbits

For the experiment 13 rabbits weighing $2.5 \mathrm{~kg}$ each were employed. They were vaccinated intramuscularly with $1 \mathrm{~cm}^{3}$ of the vaccine and revaccinated with the same dose 21 days later. Virus-neutralizing antibodies were assayed prior to vaccination (with negative results) and 21, 35, 97 and 153 days thereafter. For the neutralization tests a micromethod was employed using volumes of $0.05 \mathrm{~cm}^{3}$ and working viral dilutions of 100 to $500 \mathrm{TCID}_{50}$.

For challenges $\mathrm{AD}$ viral doses of $10000 \mathrm{LD}_{50}$ per rabbit were used and the animals were challenged $1,3,5,6,9,10$ and 11 months after vaccination.

\section{Expiration of the vaccine}

was determined in lyophilized vaccine samples stored at $+4{ }^{\circ} \mathrm{C}$ and inoculated into rabbits at various time intervals from 6 to 31 months.

\section{Results}

\section{Suitability of cell cultures for $A D$ virus propagation}

is shown in Table 2. Highest viral titers were obtained in the IBRS-2 cell line, in primary porcine kidney cells and in the PK-Č cell line. Markedly lower titers were obtained in $\mathrm{RK}_{13}$ and VERO cell lines. In testing the most sensitive cell system the cell lines PK-Č and $\mathrm{RK}_{13}$ yielded best results. By one order less sensitive were the line IBRS-2 and primary porcine kidney cells.

Table 2

Titres of Aujeszky's disease virus (in $1 \mathrm{~cm}^{3}$ ) multiplicated in different cell systems

\begin{tabular}{|l|c|c|c|c|c|c|}
\hline \multirow{2}{*}{$\begin{array}{c}\text { Titration } \\
\text { cell system }\end{array}$} & \multicolumn{7}{|c|}{ Multiplication cell system } & \\
\cline { 2 - 7 } & PK-C & IBRS-2 & $\begin{array}{c}\text { Primary pig } \\
\text { kidney }\end{array}$ & RK $_{13}$ & VERO & Mean \\
\hline $\begin{array}{l}\text { PK-Č } \\
\text { IBRS-2 }\end{array}$ & 8.3 & 8.5 & 8.5 & 6.5 & 6.4 & 7.6 \\
$\begin{array}{l}\text { Primary pig } \\
\text { kidney }\end{array}$ & 7.7 & 7.7 & - & 5.3 & 5.0 & 6.4 \\
RK & 8.3 & -5.2 & 7.8 & 4.8 & 4.8 & 6.4 \\
Mean & 8.0 & 8.0 & 8.0 & 5.9 & 7.2 \\
\hline
\end{tabular}

\section{Virus inactivation}

is shown in Table 3, indicating a perfect inactivation of the $\mathrm{AD}$ virus by glutaraldehyde at $0.1 \%$ and higher concentrations. 
Table 3

Effect of glutaraldehyde concentration on inactivation of Aujeszky's disease virus

\begin{tabular}{|c|c|c|c|c|c|c|c|c|c|}
\hline \multirow{2}{*}{$\begin{array}{c}\text { Glutaraldehyde } \\
\text { concentration } \\
\%\end{array}$} & \multirow[b]{2}{*}{$\begin{array}{l}\text { Number } \\
\text { of mice }\end{array}$} & \multicolumn{6}{|c|}{ Dead mice on different days after administration } & \multirow[b]{2}{*}{ Survived } & \multirow[b]{2}{*}{ Dead } \\
\hline & & 1 & 2 & 3 & 4 & 5 & 6 & & \\
\hline $\begin{array}{l}0.025 \\
0.05 \\
0.1 \\
0.2 \\
\text { Non-inactivated }\end{array}$ & $\begin{array}{l}\mathbf{5} \\
\mathbf{5} \\
\mathbf{5} \\
\mathbf{5} \\
\mathbf{5}\end{array}$ & $\begin{array}{l}0 \\
0 \\
0 \\
0 \\
5\end{array}$ & $\begin{array}{l}0 \\
0 \\
0 \\
0 \\
-\end{array}$ & $\begin{array}{l}2 \\
0 \\
0 \\
0 \\
-\end{array}$ & $\begin{array}{l}\mathbf{0} \\
\mathbf{3} \\
\mathbf{0} \\
\mathbf{0} \\
-\end{array}$ & $\begin{array}{l}3 \\
0 \\
0 \\
0 \\
-\end{array}$ & $\begin{array}{l}\overline{0} \\
0 \\
0 \\
-\end{array}$ & $\begin{array}{l}0 \\
2 \\
5 \\
5 \\
0\end{array}$ & $\begin{array}{l}5 \\
3 \\
0 \\
0 \\
5\end{array}$ \\
\hline
\end{tabular}

\section{Safety and potency tests}

All 14 batches of the vaccine were perfectly safe. Potency of the vaccine was tested in 13 batches. Two of them did not give satisfactory results although their AD viral titer had been sufficiently high prior to inactivation and lyophilization.

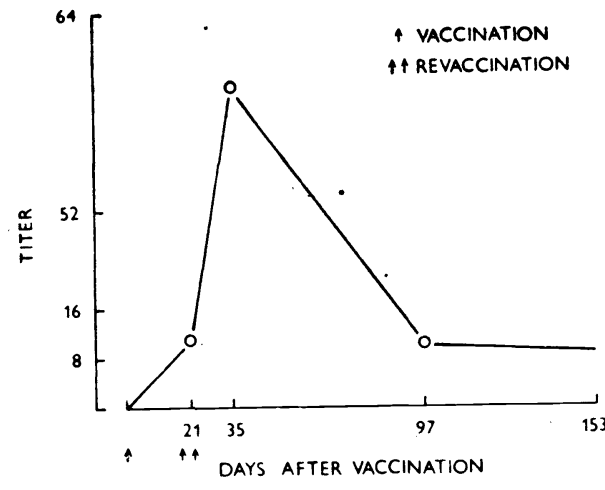

Fig. 1. Titres of virus-neutralizing antibodies in rabbits after $\mathrm{i}$. $\mathrm{m}$. vaccination and revaccination with $1 \mathrm{~cm}^{3}$

The reason of this failure remains unknown. The remaining 11 batches of the inactivated vaccine gave satisfactory results.

Post-vaccination immunity in rabbits

In rabbits vaccinated with $1 \mathrm{~cm}^{3}$ of the vaccine and revaccinated 21 days later the highest antibody titer of 51 was found on day 35 . On day 97 after vaccination an average titer of 10 was found (Fig. 1).

The control of vaccination effectiveness by challenges of the vaccinated rabbits had shown $100 \%$ of the animals to be protected $1,3,5$ and 6 months after vaccination. Fifty per cent of the animals were found to be protected 9 and 10 months after vaccination. The control, non-vaccinated rabbits died on days 5 and 6 after challenge. The results are shown in Table 4.

Table 4

Survival of vaccinated and revaccinated rabbits after challenge performed at various time intervals after vaccination

\begin{tabular}{|c|c|c|c|c|c|c|c|}
\hline \multicolumn{7}{|c|}{ Challenge - months after vaccination } & \multirow{2}{*}{$\begin{array}{l}\text { Non-vaccinated } \\
\text { controls }\end{array}$} \\
\hline 1 & 3 & 5 & 6 & 9 & 10 & 11 & \\
\hline $0 / 8^{*}$ & $0 / 3$ & $0 / 3$ & $0 / 3$ & $1 / 1$ & $1 / 1$ & $1 / 0$ & $12 / 0$ \\
\hline
\end{tabular}

* Died/survived

Expiration time of the vaccine

Table 5 shows good effectiveness of all vaccine samples tested in the period of 6 to 31 months. 
Table 5

Results of potency tests carried out with vaccines stored at $+4^{\circ} \mathrm{C}$ for determination of expiration time

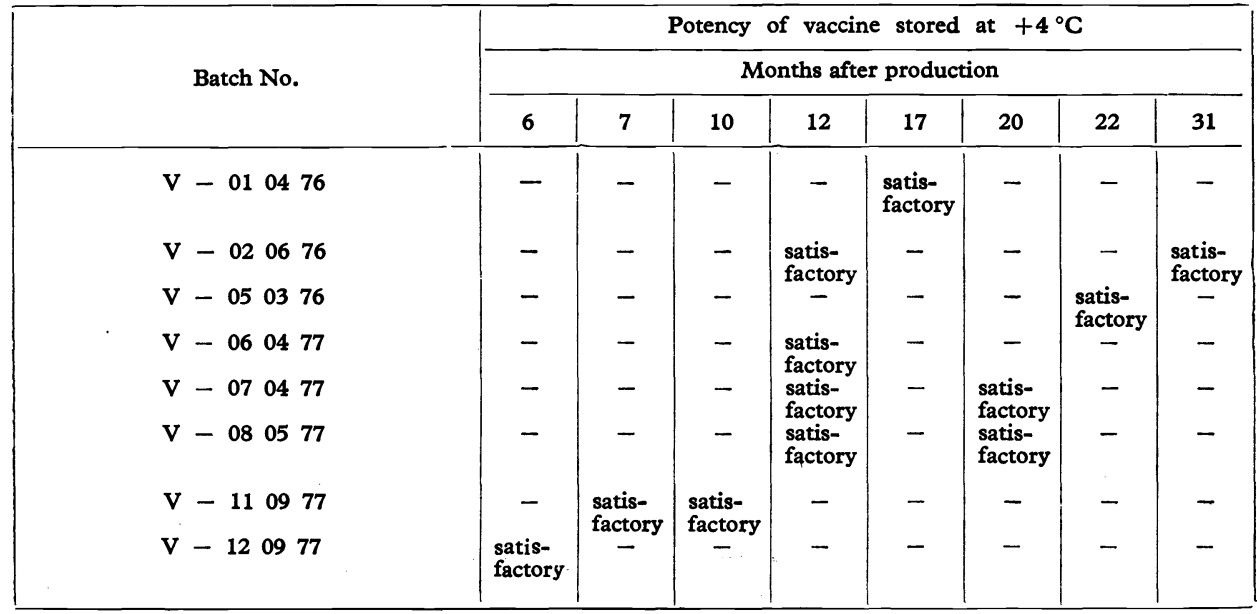

\section{Discussion}

Vaccines containing a live, avirulent $\mathrm{AD}$ virus generally confer excellent immunity but the persisting residual virulent virus may limit their use (Delagneau at al. 1975; Lai and Jong 1980). Therefore in several countries including Czechoslovakia possibilities have been explored to produce inactivated vaccines against $\mathrm{AD}$ suitable for immunoprophylaxis in swine.

This paper presents preliminary results obtained at preparation of the inactivated vaccine against $A D$. Among various cell substrates for virus propagation the most suitable were the cell line IBRS-2, PK-C and primary porcine kidney cells. The viral titer yields in these cell line cultures are comparable with data of other authors (Delagneau et al. 1975; Frescura et al. 1977). Glutaraldehyde-inactivated $A D$ virus was entirely safe for mice and rabbits. Our results of AD virus inactivation by glutaraldehyde are comparable to those published by Toma et al. (1975).

The two-component form of the vaccine (i. e. lyophilized inactivated viral antigen and the lipoid adjuvant) proved advantageous since in this type of vaccines the decrease in effectiveness is smaller than in those adjuvanted during the manufacturing process. Effectiveness of this vaccine proved to be high in rabbits as shown by good immunogenicity of the glutaraldehyde-inactivated $\mathrm{AD}$ virus. Vaccination and revaccination of rabbits with $1 \mathrm{~cm}^{3}$ of the vaccine generated a 100 per cent immunity 6 months thereafter. A protection period of 7 months in rabbits experimentally infected by AD virus reported Toma et al. (1975). Another study of our laboratory presents the results reporting on the use of the inactivated vaccine in immunoprophylaxis of the Aujeszky's disease in pigs (Jeřábek and Dedek 1981). 


\section{Zkušenosti s přípravou inaktivní vakcíny proti Aujeszkého chorobě}

K pomnožováni viru Aujeszkého choroby pro př́pravu inaktivní vakcíny je nejlépe použít buněčnou linii IBRS-2, linii PK-C nebo primární prasečí ledvinové buňky. Glutaraldehydem inaktivovaný virus Aujeszkého choroby je naprosto neškodný pro myši a králíky. Ưčinnost inaktivni vakcíny byla ověřena na králících. Vakcinací a revakcinací byla u všech králíků zajištěna imunita po dobu 6 mésíců. Lyofilizovanou inaktivní vakcinu je možno dlouhodobě skladovat bez ztráty jeji účinnosti. Zředovač, kterým se vakcína ředí bezprostředně před použitím, obsahuje lipoidní adjuvans.

\section{Опыт изготовления инактивированной вакцины против болезни Ауески}

Для размножения вируса болезни Ауески с целью изготовления инактивированной вакцины наиболее удобно использовать клеточную линию IBRS-2, линию РК-С или первичные свиные почечные клетки. Глютаральдегидом инактивированный вирус болезни Ауески является совершенно безвредным для мышей и кроликов. ӘФФективность инактивированной вакцины была испытана на кроликах. Вакцинацией и ревакцинацией был у всех кроликов обеспечен иммунитет продолжительностью 6 месяцев. Лиофилизированная инактивированная вакцина может сохраняться долговременно без потери ее эффективности. Разбавитель, с помощью которого вакцина разбавляется непосредственно перед применением, содержит липоидное вспомогательное средство.

\section{References}

DELAGNEAU, J. F. - TOMA, B. - VANNIER, P. - LOQUERIE, R. - PRUNET, P. TILLON, J. P.: Immunisation contre la maladie d'Aujeszky á l'aide d'un nouveau vaccin huileux à virus inactivé. Rec. Méd. Vét., 151, 1975:567-575.

DILOVSKI, M.: Der Einfluss der ionisierenden Bestrahlung auf Tierviren. II. Die Wirkung einer subletalen Dosis von Gammastrahlen auf die Vermehrung des Aujeszky-Virus. Zbl. VetMed., B, 20, 1973: 250-255.

FRESCURA, T. - VIVOLI, P. - CARDARAS, P. - BATTISTACCI, L. - MOROZZI, A.: Inattivazione del virus di Aujeszky con Beta-propiolattone e preparazione di un vaccino oleoso per l'immunizzazione dei cani. Clinica vet., 100, 1977: 499-505.

GUTEKUNST, D. E.: Immune responses in swine given lipid-conjugated pseudorabies (Aujeszky's disease) viral antigens. In: International Pig Veterinary Society Congress. Proceedings. Zagreb 1978, K. B. 58.

GUTEKUNST, D. E.: Immune responses in swine given lipid-conjugated pseudorabies viral antigens. Am. J. Vet. Res., 39, 1978: 1435-1437.

JERÁBEK, J. - DEDEK, L.: Imunoprofylaxe Aujeszkého choroby prasat inaktivní vakcínou. Veterinářství, 31, 1981: 244-246.

LAI, S. S. - JONG, M. F.: Studies on an UV-light inactivated pseudorabies virus vaccine. In: International Pig Veterinary Society Congress. Proceedings. Copenhagen 1980, p. 109.

LUKERT, P. D. - DeBUYSSCHER, E. V. - BLUE, J. L.: Field evaluation of a killed pseudorabies vaccine in Georgia U.S.A. In: International Pig Veterinary Society Congress. Proceedings. Zagreb 1978, J. 5.

TOMA, B. - DELAGNEAU, J. F. - LOQUERIE, R. - PRUNET, P.: Etude d'un nouveau vaccin à virus inactivé et adjuvé contre la Maladie d'Aujeszky. Bull. Off. int. Epiz., 1975. Rapport n. 212.

WITTMANN, G. - JAKUBIK, J.: Frühstadium der Immunität nach Impfung von Ferkeln mit einer inaktivierten Aujeszkyvirus-Vakzine. Zbl. VetMed., B, 24, 1977: 569-575. 
ŽUFFA, A.: Immunogenicity of the avirulent clone BUK-TK-300/9,2 of the Aujeszky's (pseudorabies) virus in sheep. Acta vet. Brno, 41, 1972: 67-74.

ŽUFFA, A. - BRANYIK, A. - SALAJ, J. - ŽUFFOVÁ, J. - MENŠÍK, J. - ŠTĚPÁNEK, J.: Žádost o autorské osvědčení PV 681-78. Inaktivovaná adjuvantná vakcína proti Aujezského chorobe a spôsob jej prípravy. 2. 2. 1978.

ŽUFFA, A. - NEURATH, A. R.: Inaktivácia vírusu Aujeszkého choroby formaldehydom. Vet. Cas., 1962: 31-37. 